\title{
THE SUBJECT-OBJECT-RELATIONSHIP IN KARL JASPERS' PERIECHONTOLOGY: A CONTRIBUTION TO AN EDUCATION FOR OPENNESS, TOLERANCE AND EXISTENTIAL REALIZATION
}

Ferdinand Rohr

\begin{abstract}
The relationship of subject and object is commonly treated in educational theories as a question of how to connect the student with the content to be appropriated. In Karl Jaspers' later philosophy, Periechontology, we find reflections that lead to the limits of the subject-object-division, demonstrating that an absolute and final knowing of Being is impossible. He calls these reflections the fundamental philosophical knowledge that can be considered as an antidote against any totalitarism and dogmatic thinking. We have to transcend the subjectobject-relationship and to consider Being as the Embracing of object and subject. Jaspers distinguishes seven modes of Embracing. To-be-there (Dasein), Consciousness in General (Bewusstsein überhaupt) and Spirit (Geist) are the subjective and immanent modes, World (Welt) is the corresponding objective mode in immanence. Living exclusively in these immanent modes can never satisfy quietly. To find real satisfaction in life we have to transcend immanence. In Jaspers' view, the step to the transcendent modes can only occur in the concomitance of the subjective and objective side, Existence (Existenz) and Transcendence (Transzendenz). It is in Jaspers' philosophical (not religious) faith that humans find identity with themselves at the moment when they recognize a cipher of Transcendence as an absolute value. The seventh mode is Open Reason (Vernunft). This mode allows all modes to be contemplated in their own sense and unified in the decisions we take that guide our lives. The purpose of this article is to elucidate the pedagogical thinking, underpinned by Jaspers' Periechontology, which is characterized by openness, tolerance and existential realization.
\end{abstract}

KEYWORDS: Subject-Object-Relationship. Periechontology. Educational Theory.

\section{RESUMO}

A relação sujeito-objeto está sendo comumente tratada em teorias educacionais sob o viés de como o educando pode entrar apropriadamente em contato com os conteúdos. Na filosofia tardia de Karl Jaspers, na sua Periechontologia, encontramos reflexões que levam para os limites da cisão sujeito-objeto, demonstrando que um conhecimento absoluto e final do Ser é impossível. Ele chama essas reflexões de conhecimento filosófico fundamental, que pode ser considerado antídoto contra qualquer totalitarismo e pensamento dogmático. Precisamos transcender a relação sujeito-objeto e considerar o Ser como Todo-Abrangente de sujeito e objeto. Jaspers distingue sete modos do Todo-Abrangente. Ser-Aí (Dasein), Consciência em Geral (Bewusstsein überhaupt) e Espirito (Geist) são os modos subjetivos e imanentes, Mundo (Welt) o modo correspondente, objetivo e imanente. Viver exclusivamente nesses modos imanentes nunca satisfaz realmente. Para encontrar satisfação, de fato, nas nossas vidas, temos de transcender a imanência. Na visão de Jaspers, o passo para os modos transcendentes acontece somente concomitantemente no lado subjetivo para a Existencia (Existenz) e no objetivo para a Transcendência (Transzendenz). É fé filosófica (não religiosa) de Jaspers que os seres humanos encontram a própria identidade no momento em que reconhecem alguma cifra da Transcendência como valor absoluto para si. O sétimo modo é a Razão Abrangente (Vernunft). Esse modo permite que todos os demais sejam contemplados no seu sentido próprio e unificados nas decisões que tomamos para guiar a nossa vida. É objetivo deste artigo elucidar o pensamento pedagógico subjacente à Periechontologia de Jaspers, que se caracteriza como abertura, tolerância e realização existencial.

PALAVRAS-CHAVES: Relação sujeito-objeto; Periechontologia, teoria educacional.

\section{RESUMEN}

La relación sujeto-objeto está siendo comunmente tratada en teorias educativas en lo referente a cómo el educando puede entrar en contacto de forma apropiada con los contenidos. En la filosofía tardía de Karl Jaspers, en su Periejontologia, encontramos reflexiones que llevan para los limites de la división sujeto-objeto, 
demostrando que un conocimiento absoluto y final del Ser es imposible. Jasper llama estas reflexiones de conocimiento filosófico fundamental, que puede ser considerado antídoto contra cualquier totalitarismo y pensamiento dogmático. Necesitamos transcender la relación sujeto-objeto y considerar el Ser como el TodoEnvolvente de sujeto y objeto. Jaspers diferencia siete modos del "Todo-Envolvente". Ser-ahí (Dasein), consciencia en general (Bewusstsein überhaupt) y espíritu (Geist) son los modos subjetivos e inmanentes, Mundo (Welt) el modo correspondiente, objetivo e inmanente. Vivir exclusivamente en estos modos inmanentes, realmente nunca satisface. Para encontrar de hecho satisfacción en nuestras vidas tenemos que transcender lo inmanente. En la visión de Jaspers, el paso para los modos trascendentes sucede solamente de manera concomitante en el lado subjetivo y objetivo, para la Existencia (Existenz) y la Trascendencia (Transzendenz). Para Jaspers, es la fé filosófica (no religiosa) en la que los seres humanos encuentran la propia identidad en el momento en que reconocen alguna cifra de la Trascendencia como valor absoluto para si. El séptimo modo es la Razón Envolvente (Vernunft). Este modo permite que todos los modos sean contemplados en su sentido própio y unificado en las decisiones que tomamos para guiar nuestra vida. El objetivo de este artículo es elucidar el pensamiento pedagógico que subyace a la periejontología de Jaspers, que se caracteriza como abertura, tolerancia y realización existencial.

Palabras claves: Relación sujeto-objeto; Periejontología; teoria educativa.

Educational theory is not conceivable as founded exclusively on the relationship of two subjects, the educator and the pupili. There is always, in some sense, something of the objective side of reality that is directly or indirectly included. We only need to ask what the educational task is that brings educator and pupil together in order to realize that education cannot be reduced to a merely subjective event. If education in its widest sense means helping the pupil to form his/her subjectivity so as to have a fulfilled, self-determined life which is underpinned by human values, there is no way we can expect that this is possible without confronting the pupil with objective reality. The way we appropriate objects determines our subjectivity. The philosophical formula is: without objectivity, there is no subjectivity. Nevertheless, the inverse is also true. If there is no subject that perceives or establishes a relationship with an object, it is for us as if that object does not exist. Therefore, to characterize the relationship between object and subject is a fundamental task for philosophical anthropology with fundamental consequences for educational theory.

Yet, these affirmations are abstract and vague. There is no consensus about what objectivity and subjectivity are. Or what kind of subjectivity is related to what kind of objectivity. We cannot speak about subjectivity and objectivity in general terms or reduce one in relation to the other and expect useful pointers for educational thinking. A large number of educational theories can be identified as reductions of educational reality exactly because of there being no very well determined and balanced relationship between the subject and object sides in human existence. In those terms, we can mention as examples first of all that the view of reality, based on Scientism, is a position that greatly overvalues the objective side and on the other hand, most post-modern thinkers, because they stress that human desire and will are central to their thinking, overemphasize the subjective side.

One of the philosophers who sought a well-balanced view of the subject-object relation was Karl Jaspers. Jeanne Hersch (1987), besides Hannah Arendt, one of Jaspers' most famous students and experts of his philosophical legacy denotes Jaspers' work as a "rational contemplation on the limits of the condicio humana." (p. 21) Furthermore, in his 
reflections he detected the opportunity to foster openness and tolerance in our thinking that includes having existential realization in our lives. We will concentrate our presentation of Jaspers' philosophy on those issues so that we may obtain pointers that aid educational thinking.

The fundamental relevance of the subject-object relation was revealed in Jaspers' analysis of the sequence of historical proposals to determine the origin, basis, and reason for all things. Ever since western philosophy began, the wish to acquire a deeper knowledge of reality has been and remains a central issue. The desire to know everything, especially the reason for everything that exists and happens, including ourselves, runs through all Ages, cultures and religions. In philosophical terms, the question is: What is Being? Jaspers alerts us to the fact, that when philosophy began, the origin of everything - the Greeks called it arche - was identified with the objective side of reality, whether this be a material part of objectivity: water, air, an atom; or an abstract principle: apeiron (the indefinite), number, idea, etc. This was the critical view of Rationalism, especially represented in Kant who provoked the question of our being alerted to the subjective side. The object we perceive is not the object itself. It is the object as it appears for us, conditioned on the capacities of our perception of objects. Kant's purpose in making this affirmation was to combat religious dogmatism. But it can be used to criticize any type of dogmatism. Every effort to express Being as any objective reality fails only because it excludes the subjective aspect of Being. The solution we normally try to give is to make the subjective part into an objective thing. Especially in human sciences we make great efforts to find merely objective expressions of subjective issues. Actually there is a great belief in the capacity of the neurosciences to explain all subjectivity (feelings, emotions, thinking) towards neurotransmitters. Jasper's answers to that intention is always the same: Every attempt to turn our subjectivity into anything that is merely objective forgets that the result cannot include the subject who commits that act. The subject itself who objectivizes is not included in the process of objectivization. In the observation of myself. I am at the same time the object to be observed and the subject that makes the observation. Every time that I try to make that subject the object of my observation, there reappears "another" subject to realize it. There will always remain a part of our subjectivity that cannot be excluded in the attempt to turn the subject into something that is merely objective. So we came to the conclusion that on the one hand there is no possibility of expressing Being as something objective and that, on the other hand, complete objective knowledge of human subjectivity is impossible. Everything that enters into our consciousness necessarily involves the objective and subjective side. Our consciousness is characterized by the division of subject and object. ${ }^{i i}$ Jaspers called it the split of subject and object. So we can identify all knowledge that intends to be absolutely truth as a reduction of the entire truth that cannot be affirmed in other than a dogmatic way.

This argumentation is the first step of what Jaspers called the basic philosophical operation. At the same time as this shows the limits of human knowledge, it liberates us from all temptations to close our knowledge in reduced and dogmatic terms. Therefore this shows that Ontology as an adequate and final knowing of Being is impossible. The basic 
philosophical operation can be considered the antidote to any dogmatic thinking. It proves that all knowledge that is considered as absolute truth definitely cannot be so. The question is whether that basic philosophical operation opens the door to a radical relativism, based on the fact that we can never totally exclude the subject side of our thinking. Jasper's answer is: Not necessarily. We can get further perspectives if we confront ourselves with the question: is there anything beyond that division of subject and object side, any reality that includes both? His answer is affirmative. He called the reality as a whole of the subject and object side, Encompassing. "Encompassing is that all Being exists for us; or it is the condition, in which Being can be really Being for us. It is not the sum of Being but it is that which always remains for us, the enclosed ground of Being." (Jaspers, 1947, p.39) It is the space where the object appears for the subject but is not itself subject nor object. So we cannot have knowledge of it. "The Being that I know is not Being in general and not the Being that I am myself." (Jaspers, 1947, p.37) That does not mean that we have no access whatsoever to it. The Encompassing is not another, a per se, inaccessible Being. Rather, it is present in appearance, and therefore it can be made perceptible indirectly. (see Jaspers 1947)

Trying to think about this, leads us to a paradoxical phenomenon. All we think, we think as an object but in reality, Encompassing is not an object. At the same time as we think of it as an object, we have to recognize that this thinking is not adequate for Encompassing. Therefore the concept of Encompassing leads us to a difficulty that, for Jaspers, is the difficulty of philosophy itself.

Any affirmation in relation to Encompassing includes an illogicality in itself. It

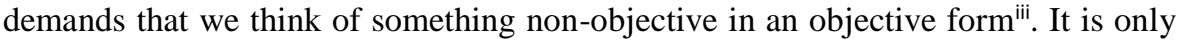
because this is possible that philosophy is possible. But exactly that difficulty permits our thinking existence to change so [...] that it is, as it were, broken open and become wide and lucid. (Jaspers, 1947, p.40)

This change is immensely important because it transforms our consciousness of Being.

\begin{abstract}
What is contradictory logic for common understanding is still executable philosophically as becoming lucid (Hellwerden) of a consciousness of Being that is incomparable with any determined knowledge. That consciousness is the fundamental disposition (fundamental posture, fundamental constitution) of the philosophising human. The concept of Encompassing is an initial getting clear of that fundamental disposition. (Jaspers, 1947, p.39)
\end{abstract}

That does not mean that we abandon all logic and rational thinking.

\begin{abstract}
Meanwhile the concept (of Encompassing) liberates us from absolute submission under a knowable order. It nevertheless lets us seize all sinful order, but as a tool or a way or a scheme, not as a basis for Being, not as ontology, theology, or system. This concept teaches us to seize in a game what has the seriousness of a language, teaches us to float, without plunging into the bottomless pit, to be carried without creating roots. (Jaspers, 1947, p.42)
\end{abstract}

So we cannot have any direct knowledge of Encompassing, we can only believe in its existence, which, in Jasper's terms, means adherence to a philosophical faith ${ }^{\text {iv }}$. When we negate its existence we opt for nihilism. If we search for our access to that belief, to underpin \begin{tabular}{l|l|l|l|l|l|l} 
(C) ETD - Educ. Temat. Digit. & Campinas, SP & v.18 & n.3 & p.596-613 & jul./set.2016 & ISSN 1676-2592
\end{tabular} 
our belief in it, we only have our self-reassurance about reality and our disposition towards it (see Jaspers, 1962). It is not a faith acquired in some external way, as divine revelation or testimony by others. We attain it when we reach the state of feeling secure in our own convictions.

The question of how we find ourselves in Encompassing, in Jasper's thinking, cannot be answered in only one way. Our self-reassurance of Encompassing leads us to distinguish different origins in it, both on the subjective as well as on the objective side. Jaspers identified seven different origins in Encompassing. He called them modes of Encompassing. In the following we present the basic characteristics of these modes and the relationships between them. We begin with the Dasein. Expressed in a most simple way, we can say: "Dasein is enunciated by 'I am here', 'we just are here'." (Jaspers, 1947, p.53) Fundamental for its comprehension is that "Dasein is the directness in which we find ourselves in the Being, the sensation and experience of a life in our world" (Jaspers, 1947, p.54). As my immediate relation to my life is always individual, "it is my Dasein". (Jaspers, 1947, p.54) "Surely it has outlines that we can elucidate as Dasein in general, but nevertheless in a way that this Dasein cannot be universal, but rather essentially as that which is fulfilled, always a unique and single Dasein." (Jaspers, 1947, p.54) This single Dasein lives in its very own world. It is situated in a space "in which we notice things, in which we have many kinds of perceptions, and in which we react to our experiences with constructions that we arrange unconsciously". (Jaspers, 1947, p.54) Therefore, we cannot comprehend it as an unchanging reality. "Dasein always arises anew, is born and dies, has a beginning, is an asset for a while and succumbs at last, cedes space to another Dasein that, for its part, declines into the same fate." (Jaspers, 1947, p.54) This dynamic of Dasein is moved by desire, instinct, impulse and will.

It claims its satisfaction and felicity. It may be that it reaches, in some exceptional situation, the state of completeness. Nevertheless, these moments are always transitory, without continuance. In other cases, we lose it in a short time or our interest in it vanishes with time. (Jaspers, 1947, p.54)

Dasein is at all times under threat. To continue to be alive, it must fight or others have to do so. Therefore it must be constantly aware of the most varied dangers that menace us in our Dasein. As we can never have assurance, fear forms part of Dasein. (see Jaspers, 1947, p.54) In some situations the will of absolute assurance can bring people to try summoning up their will for power (Nietzsche) to absurd levels. (see Jaspers, 1947, p.54) We notice that Dasein includes more on the biological aspects yet also psychological and social ones. So it can be the object of a scientific investigation. But Jaspers alerts:

In science we necessarily make an object of Dasein. That is an inadequate temptation. In the sciences, we necessarily make some part of Dasein an object. By this act, Dasein loses the character of a mode of Encompassing that is only accessible by philosophical elucidation. Elucidation means here an inner perception of what I am as a living being, as what I myself make present to myself. (Jaspers, 1947, p.57) 
We have seen, that all that which is real for us enters our Dasein. But there are some realities in Dasein that have another origin. We begin with the mode that Jaspers, drawing on Emmanuel Kant, called Consciousness in General. It is the thinking that is "aware of itselves when directed to something of the Dasein. (cogito ergo sum)" (Jaspers, 1947, p.64).

But we must distinguish the consciousness of the Dasein, the innerwardness of our individual life from the Consciousness in General "as the consciousness that in everyone is the same consciousness with which we are directed to the being that has formed objective being, meaning, perceiving, feeling in an identical way." (Jaspers, 1947, p.65) Consciousness in General is common to everyone. "Differences are not modifications of the same sorts of things, but they are errors, which means untruth." (Jaspers, 1947, p.57) So we detect an essential difference between Dasein and Consciousness in General which means it is a matter of another origin in Encompassing.

General characteristics of Consciousness in General are: it

\begin{abstract}
$[\ldots]$ is limitless: It includes all that can be meant by us in an objective manner and it becomes present through objective meaning. But in a way that, in that meaning, makes something valid present, the truth that, provided we understand it, is cogent. Because of the Consciousness in General we form part of a realm of withstanding and valid sense and reach with it as far as is possible towards some form of universal validity. (Jaspers, 1947, p.67)
\end{abstract}

It represents all forms of universally evident knowledge as logic, mathematics and scientific findings. Therefore, Conciousness in General is the realm in which Cartesian thinking is appropriated. ${ }^{v}$

A very polemical question in contemporary philosophy is whether Consciousness in General is possible or if it is constantly influenced by the most different expressions of our Dasein. Jaspers' position is clear "Consciousness in General is independent of the Dasein." (Jaspers, 1947, p.68) That is because

[...] the contents and directions of this thinking must not necessarily have an influence on the motives of the Dasein. Even if these motives lead throughout the thinking to bedazzling or seducing illusions, the independent origin of the consciousness can, in correct understanding, work out itself always more freely. (Jaspers, 1947, p.57)

When we affirm that Consciousness in General includes all universal validity, which at the same time means that it is timeless, it only the intended sum of its contents that is timeless, not the process in which we grasp it. We recognize universal validity at a certain moment, but nevertheless it itself is timeless. Because it is unlimited, nobody owns it entirely but everyone has, to a greater or lesser, a share of it. The wider our Consciousness in General is, the clearer the view that we can have of our Dasein.

The third immanent and subjective mode of Encompassing is the Spirit. 


\begin{abstract}
We are Spirit as the Encompassing that projects with its fantasy creations and realizes in works and shapes a world filled with sin. It is different from rational computability and the production of tools and machinery because of Consciousness in General. In contrast to the darkness of irrationality of the Dasein, it is the process of revealing in the moment of understanding and becoming understandable. (Jaspers, 1962, p.114)
\end{abstract}

Jaspers distinguishes three kinds of understanding, namely: "Rational understanding which meets the sense of thinking within the Consciousness in General. Secondly, psychological understanding which meets the motives of the Dasein. And thirdly, Spiritual understanding which meets the meaningful contents that can be found in the creative bringing forth as something valid that appears to us." (Jaspers, 1962, p.114/5) Therefore the creativity of the Spirit is not random. "The object of the Spirit is not the created object but that which was founded in the process of creating. Its own objective form is the power of a whole that is effective by order limitation and measure." (Jaspers, 1962, p.115) So Spirit always look out for expressions of wholeness that brings human thinking, feeling and acting together. At the same time, we have a "comprehension of the whole as a target it germinates in us, and actuates to bring forth more forms constantly. The whole that is objectivized by the human Spirit is called idea." (Jaspers, 1947, p.71) This Spirit is inserted into an infinity of ideas and is engaged on appropriating them. That means that the Spirit is always looking for its objective expression. "The subject of the Spirit is fantasy. It plays around with its creations. It establishes the meanings. It makes them touchable in symbols. It gives all that can be, linguistic expression." (Jaspers, 1962, p.115) Therefore, Spirit creates an impersonal object in a personal form and never reaches a universal comprehension. (see Jaspers, 1962, p.115) That is why the Spirit finds itself in a never-ending movement. "Starting from its origin, it brings structure to this endless material. Its ideas create interconnections in the multiple and finite purposes of my acting." (Jaspers, 1947, p.71/2) The objective world acts as a stimulus to go on creating. The presence of ideas in words and creating allows the Spirit to comprehend itself: "in works of thinking, of art, of poetry; institutions, laws and constitutions; in professions; in morals, and life regulations. Its movement of comprehension only happens in the grasp towards an objectivization and in the creation of new objectivizations" (Jaspers, 1947, p.76). Without the objectivity of created ideas to work on, the Spirit, as merely subjective, is chaotic. Its Encompassing appropriates reality in an understandable way, includes what belongs but nevertheless extinguishes the respective strange. (see Jaspers, 1947, p.71; 1962, p.115)

The mode of the objective side that corresponds to Dasein, Consciousness in General and the Spirit, Jaspers denominates as World. We have just noticed it was impossible to describe the subjective modes without mentioning their objective correspondence. The subject modes themselves form part of the World and do not exist without the World. Dasein emerges in the Word and needs it as the environment in which to persist and keep living. Consciousness in General has all logical, mathematical abstractions and scientific categories as its objective correspondence in the world. The ideas created by the human spirit are 
materialized objectively in the most varied works. Nevertheless, World as the mode of Encompassing is not merely the sum of what we perceive as immanent subject. "Being World is the ungraspable other. It itself is not a thing and not Being I. What the world is itself as being is that in itself it is Encompassing, that is the inaccessible secret of the Being different" (Jaspers, 1947, p.89) As such it cannot be known as a whole. "It is the ground and origin of reality." (Jaspers, 1947, p.90) In philosophy we can find a lot of different notions of the World. The World as mode of Encompassing cannot be expressed in any concept, notion or idea. It is a never-ending temptation to think the World as a whole. Spinoza demonstrates the necessary consequence: "nature sive deus" (Jaspers, 1947, p.90) The World in that case forms something absolute for us. "The World would be one with God, and God nothing other than the whole of the World," (Jaspers, 1947, p.103) Not even rarely is the modern scientific conception of the world based on that presupposition, without reflecting its consequences. All temptations in that direction do not resist in the light of what we called fundamental philosophical operation. Therefore, "We have to make the philosophical step to bring all that is objective, that means, all knowable being to float completely. The bottomlessness of the World must become obvious so as to make possible the truth of knowing in the world." (Jaspers, 1947, p.104) That truth can only be limited truth.

The modes of Encompassing presented to this point are unquestionable reality for us.

The further question is if that immanence is sufficient to itself or if it points to some other. It is a matter of fact that humans affirmed that there is only immanence and believed they could live in that knowledge. In such a posture, immanence would be enough for them and out of it is nothing. Nevertheless, during all historical periods, humans made the jump out of immanence: immanence does not fulfil, they become aware of the forlornness in it, they discovered that immanence does not consist of itself, that it cannot be comprehended by itself. So they did the transcending jump, in fact at once, from the World to Godness. And from the Dasein of thinking Spirit to Existence. (Jaspers, 1947, p.49)

That insufficiency reveals itself in each mode in a specific way. We have to ask ourselves and decide what we really are. "Am I only the ruthless self-will of my Dasein, only the substitutable point of correct thinking, only the blossoming of the Spirit - a beautiful illusion?" (Jaspers, 1962, p.116) There is no space in immanence to realize ourselves truly, to reach a real satisfaction. To be really ourselves we have to transcend immanent reality. ${ }^{\mathrm{vi}}$ Jaspers called the subjective mode of Encompassing that allows us to transcend the three immanent subjective modes: Existence. "The grounds of our selfhood - the hidden constitution from which I come towards myself." (Jaspers, 1962, p.116) That means "Existence is not suchness, but the possibility that I can become myself (Seinkönnen)." (Jaspers, 1962, p.118) In any situation and principally in our boundary situations, that means, the situation from which we cannot escape by any means as human beings, such as illness, death, uncertainty, wonder, suffering and guilt, in which we are forced to decide. These decisions are not only about practical and pragmatic issues, independently of what we ourselves are. "Existence is constantly towards the option to be or not to be." (Jaspers, 1962, p.118) It is the deep experience that I can lose myself, I can act in a way that I cannot identify myself with, even when it is my decision and what I am doing. The decision about Existence 
is always a decision about me myself. "I only am in the seriousness of my decision." (Jaspers, 1947, p.60) It is not possible to take in existential decision without being totally committed to it, of acting according to it. What is about the game for Existence is me and nothing is more important than that. I do not own myself as possession, but I am able to come to me in my decisions. vii Affirmations like that are common in the philosophy of Existence. But they are ambiguous. We can confuse existential decision with arbitrariness, with decisions in the mode of Dasein.

As I perceive my possibility to decide, and not merely the faculty of arbitrarily choosing Dasein, rather as the possibility of a decision through its necessity I am myself, I am able to see in the ground of the possibility of decision, the possible Existence: What I am, I become due to my decisions. (Jaspers, 1962, p.119)

So that decision is not merely subjective, and the criticisms of exaggerated subjectivism in the Philosophy of Existence are not justified in Jaspers' case. We have to feel existential decision as necessity. That means we have to reach the point of saying: It is impossible for me to decide and act differently. If I decide or act differently, I lose myself. That does not mean that it is not possible to lose ourselves. We can affirm in a general way that this is the most common posture. In everyday life, humans rarely attempt to question whether or not they are themselves. Normally we live in the way that it is common to live in and make decisions. We form part of a mass and think and act in it and reproduce its patterns. In this case, we have not yet made the transcending jump from immanence to transcendence. We have not yet perceived what can become necessity and unconditional for us.

The experience that Existence is not arbitrariness and confronts us with something that has become absolute for us, is the experience of Transcendence as the objective mode of transcendent Encompassing. On doing so, we touch one of the most characteristic traits of Existence in Jaspers' thinking which has its origins in Kierkegaard. It is the deeper structure of Existence that distinguishes it from nihilistic existentialism. "Existence is the self that leads itself to itself and knows that itself is related to the power, through which it is positioned" (Jaspers, 1962, p.118)

That means Existence "is freedom not without Transcendence by which it recognizes itself as a gift". (Jaspers, 1962, p.118) The consequence is that Existence is freedom but not by itself. We have not created ourselves as free beings. Freedom can fail to appear. In many moments of our life, we can have doubt about ourselves. We do not have security about what is the decision and acting that corresponds with us. Many different motives enter into conflict with each other. Principally, when we begin to perceive what really there is to do and we notice that it is very difficult or painful to do. Then what can easily happen is what Nicholas of Cusa expressed in very uncouth words: 'Reason (Verstand) is the prostitute of our will.' When our will does not want to realize what is necessary to be authentic with ourselves, our reason charges itself to find arguments to desist from the realization of ourselves. Then we negate Existence and with it Transcendence. It is different when we in fact have the determination to unconditionally accept what becomes for us absolute. Then we are grateful and realize ourselves disregarding all negative circumstances which it carries with it and we 
feel existentially free at the same time as the result of our effort and as something that we are presented with. "Existence is the effort to be authentic with ourselves. [...] Moreover, such decisions are only founded in Existence if we make them recognize the presence of Transcendence. Existence means: the possibility of being authentic before Transcendence.' (Jaspers, 1962, p.119)

One of the most important consequences of freedom, in what I assume what reveals absolute to me, is the recognition that this absolute is not an absolute for everyone. It is essentially valid only for me. "Existence is the ever only one, as that being itself, irreplaceable and irretrievable." (Jaspers, 1962, p.118) My own effort to find what is unconditional for me shows me that it will not remain the same if I try to transfer it to others. viii But that does not mean that we are Existence in isolation to others. "Existence can only be in communication of Existence." (Jaspers, 1962, p.120) "As an isolating being-formyself selfhood that is no longer being with itself. It comes to itself only in communication with another self that comes to itself. Therefore fighting Love belongs to existence. [...] In no isolated truth does truth remain." (Jaspers, 1962, p.120) Therefore the relationship between Existences is characterized at the same time by love and fighting. Both are fighting to contribute that the other becomes authentic with itself. That means love. Neither allows the other to decline realizations oriented by mere immanence. To become Existence is a neverending process. All realizations of Existence are historic ones but at the same time go beyond time. At a certain moment Existence transcends the historical reality and perceives something valid that is independent of the historical situation. Therefore we can characterize Existence "as a coming to itself of the self when there is a becoming present of something eternal". (Jaspers, 1962, p.120)

To comprehend these affirmations better, we need to outline what Jaspers means by Transcendence. First, in his understanding, there is no way by which we can know what Transcendence is. "Transcendence does not manifest itself as being in its adequate appearance in the World, $[\ldots]$ but only in historical language, created at the same time by humans." (Jaspers, 1947, p.110) Even though Transcendence as itself is unrecognizable, this does not mean that we cannot have access of some kind to it. "As Existence we think in the direction of Transcendence in objects we call ciphers." (Jaspers, 1962, p.153)

\footnotetext{
Ciphers shine in the ground of things. They are not knowledge. What is being thought in them is vision and interpretation. They escape universal experience and verifiability. Their truth lies in the connection with Existence. The attraction of Transcendence acting on Existence becomes speech in them. They open spaces of Being. They make it clearer for what I myself decide. (Jaspers, 1962, p.153)
}

We can find ciphers of Transcendence in all religions, and cultures, in myths, literature and legends. But it is not restricted to them. "All that is and was created by humans: realities, imaginations, thoughts" (Jaspers, 1962, p.193) can become ciphers. "We can find them in the mystical, religious, cultic, sacral, in the practical and artistic tradition as well as in Philosophy." ' (Jaspers, 1962, p.116) They are at their most common in history but what also is continuing on a large scale nowadays is that they are recognized as facts in the World,

\begin{tabular}{l|l|l|l|l|l|l}
\hline (C) ETD - Educ. Temat. Digit. & Campinas, SP & v.18 & n.3 & p.596-613 & jul./set.2016 & ISSN 1676-2592
\end{tabular}


$[\ldots]$ as physical realities in space and time. [...] The great step, with which the human transformed himself, has been taken when the alleged corporality of Transcendence was relinquished as a fake reality in favour of hearing the ambiguous language of ciphers. (Jaspers, 1962, p.154)

Transforming Transcendence into a knowable object, into something that in fact exists as a corporality in the world is an act that can have devastating consequences, when it turns into a dogmatic form of faith ${ }^{\mathrm{x}}$. In philosophical terms it represents a lack of truthfulness. Nevertheless, ciphers appear initially as objects in our historical world. But in an existential sense they are more than that. They are necessarily transformed into significance for our Existence that transcends it as a mere aesthetic or historical object. Therefore a cipher of transcendence is not an object, nor is it Transcendence itself, it mediates Transcendence without making Transcendence touchable.

We can feel their earnestness when we orient ourselves on them as images and guides in our existential moments. "It depends on truthfulness to appropriate the ciphers purely." (Jaspers, 1962, p.155) The truthfulness of a cipher is based on the relationship that we detect having with them, when we try to capture its innermost meaning. "Interpretation of the ciphers can gain truth only from the origin of the interpreter. He must be kindred with the origin they arose from or in which they are heard." (Jaspers, 1962, p.118)

These reflections about the jump from immanence to transcendence in its possible realization as Existence seems to be the complete fulfillment of human life. Nevertheless, Jaspers completed his philosophy with one more mode of Encompassing. The insufficiency that remains is based on a fundamental desire of human being: to overcome disunity as a fundamental experience of our lives. Endless manifoldness forms part of reality. Every mode of Encompassing is unclosed and unclosable.

Dasein and Human Spirit are in their incalculable individualizations infinite. The Consciousness in General indeed is in its own sense one but in its appearance since it depends on the numberlessness of its participating thinking points. Existence consists of the relation to each other and in its oppositions of many Existences. The World is born in the manifoldness of its aspects, the possibilities of explorations, the sheaves of objects. The one Transcendence speaks in the plurality of the historical appearance of ciphers to the Existence that can hear and perceive them and is like the one of reality itself inaccessible." (Jaspers, 1962, p. 126)

So far we have discussed six modes of encompassing: To-be-there (Dasein); Consciousness in General (Bewusstsein überhaupt); Spirit (Geist); World (Welt); Existence (Existenz) and Transcendence (Transzendenz). The seventh mode of Encompassing that confronts with the radical recognization of the manifold and interminable nature of reality and the never satisfied will of oneness is what Jaspers calls Vernunft. Vernunft is a word that cannot be translated by Reason without further explanation. Philosophically we have to distinguish between the German words Verstand and Vernunft. In everyday language these terms are often used as synonyms. For Jaspers, Verstand is what we have seen as Consciousness in General. This means the thinking that is identical in everyone. "The difference consists of the fact that Verstand determines, fixes and limits and thereby makes thinking clear and distinct. Vernunft opens, moves, does not find any rest in a something 
known." (Jaspers, 1962, p.128) Vernunft cannot exist without Verstand and will never abandon it. But Vernunft is greater and has another origin. By promoting the interminability of reality, "we nevertheless also feel the indelible will to oneness, to where everything pertains to everything, is in connection with everything else, where nothing is in vain, futile, needless, where nothing falls out and nothing is forgotten." (Jaspers, 1962, p.126) As the bond of all, Vernunft "does not allow an absolute disintegration, the pursuance of disunitedness that is endless. It will not accept that something disintegrates definitely, falls out of Being, sinks into the bottomless pit and disappears." $x i$ (Jaspers, 1962, p.127) At the same time the Vernunft does not allow us to believe that oneness is reachable. "The aim [of oneness] as something reached in fact is unthinkable and unimaginable for us. If anyone claims to have anticipated having reached it, he/she destroys it." (Jaspers, 1962, p.116) So Vernunft is constantly in movement, is fluctuating between the motivation to gather everything without covering over the differences.

A very interesting question of our topic is "How the subject-object-relation is determined in thinking the Encompassing of Vernunft?" (Jaspers, 1962, p.127) What is the subject here and what is the object in the split? The answer is surprising:

There, the structure is fundamentally different as in all other modes of Encompassing. Vernunft enters all modes of the subject-object-split. Nevertheless in itself it is without such a split. Therefore it is as if it were nothing, when it does not enter the reality of the other modes of Encompassing. It does not find another, new objectivity in the form of a new subject that is opposed to that. It acts in conjunction with Existence, which confers earnestness to it. It is the movement in the World, abstracted from the one that is beyond all that is thinkable and to which all is directed. (Jaspers, 1962, p.127)

So Vernunft has no proper object, nor can it be isolated as an attribute of the subject. Notwithstanding Jaspers identifies Vernunft with philosophizing "That sounds extraordinary [...] It seems that our breath ran out, where not even object and subject are opposed." (Jaspers, 1962, p.127)

Indeed, here in this mode of Encompassing lies the room of the movement of entering which is the purpose of philosophizing. But it cannot fulfill itself in a space without air, rather it must step into all modes of Encompassing, whose contents only become clear and pure, whilst they search in all directions for the bond, by which they attain the oneness. (Jaspers, 1962, p.129)

With that description of Jaspers' periechontology, we are able to determine what Jaspers understands by philosophical faith:

The fulfillment of Encompassing, in which neither object nor subject is lost, rather both remain present in Oneness, we call faith in the widest sense and the reassurance, reassurance of faith. Faith in its increased and embracing immanent sense, we encounter in the reassurance of Existence and Transcendence. The reassurance of Vernunft (reason in its broadest sense) as the imperative sense in philosophizing elucidates the faith in Vernunft, which belongs to philosophical faith as its truest power. (Jaspers, 1962, p.142)

Therefore, it is an essential moment in Jasper's philosophy that we keep "an unreserved will to our self-reassurance about reality," (Jaspers, 1962, p.139/40) namely, all 
the modes of Encompassing. On all occasions, this is due to seeing for ourselves what we can accept as our own convictions. That is the indispensable "approach to philosophical faith: the willingness to unlimited openness. (Jaspers, 1962, p.140)

So Jaspers proposes in his periechontology three main steps that are relevant for educational thinking: The first is from the ingenuous view of reality, in which we simply identify our perception of reality with reality itself to the insight that all reality only is as it appears to us. All that is for us, all that we can have consciousness of, must enter into the subject-object split. The step of faith is to believe that there is a reality that embraces subject and object, Encompassing. The second step that needs an act of faith is the jump from immanence to transcendence. We can widely demonstrate the senselessness, in the last resort, of immanence but nevertheless we cannot force someone to accept that there exists anything that can become absolute for him. In the same way, we can demonstrate that all wholeness that humans believed to be final, is a fake. But we never can compel anyone to find the sense of his life by entering into a never-ending search for wholeness, convinced that it is not possible to obtain it.

So we comprehend clearly that our pedagogical reflections about Jaspers' thinking cannot consist of a certain number of pedagogical rules, and didactic and methodological suggestions. It is worth knowing that the only article that Jaspers wrote exclusively about education is entitled: 'On the limits of pedagogical planning'. Jaspers does not condemn planning for some types of pedagogical tastes and human acting in general. "Planning, constant planning is necessary for us, humans. It is not against Planning, rather the protection that is necessary is to be against a false spirit of Planning and against a planning that intends to include what is not graspable." (Jaspers, 1983, p.19) All the three steps mentioned belong to the reality that cannot be planned, to the realm of freedom. If we try to force decisions of that nature, or even use the most subtle manipulation to get the pupil to take one of these steps, we pervert what we are longing for. In the realm of freedom, pedagogical acting must be indirect, can only prepare the favourable conditions that allow the pupil to come to his own decision. But what this is to be we begin to respond to with some observations on the fundamental philosophical operation.

We have characterized it as an antidote of radical and dogmatic thinking. Principally in the education of young people in adolescence, just as they are entering phase in which they firm up their own positions and convictions, reflecting on the fundamental philosophical operation can work as a means to prevent dogmatic thinking which characterizes that age group. Every attempt to settle on one's own position can be answered with Socratic irony; that means, showing the pupil that in fact he does not know what he believes that he knows.

That is not an easy educational task, in a period characterized by a vast belief in science as offering the final truth about reality. Jaspers frequently called this the superstition of Science, when we lose clear consciousness of the limits of science such as inevitable propositions, methods and the delimitation of the object to be investigated. It is just at that point we enter into the educational importance of Consciousness in General. The questions 
we constantly need to tackle with the younger generation is: what can we know with universal certainty and what is a question of individual knowledge? With that latter question we confront ourselves with what Jaspers considers the basic task of philosophising about Encompassing: to distinguish the different origins we can find in it and to make them as clear as possible.

That is not a mission that can be resolved by having some units of apprenticeship. We have to appropriate the habit to make distinctions between the origins of our feeling and thinking whenever we make decisions that are significant for us. What is the type of certainty that I have? Is it a vital impulse, is it general and undoubtable knowledge, is it an idea that can have different significations for every individual or does it concern me in an existential sense? Jaspers called this type of questioning and self-reflection "philosophical meditation" (Jaspers, 1962, p.94). This meditation is not only a helpful instrument in our existential situations but Jaspers considers it as a necessary daily exercise for a philosophical life.

I remember what I did think and feel during the day. I examined what was wrong, when I was untruthful with myself, what I wanted to cower away from, when I was not being sincere. I see where I confirm myself and where I can improve. I become aware about the control that I am exercising over myself and in what way I hold tightly to it during the day. I judge myself - about single attitudes - not about the inaccessible whole that I am - I find the principles that I will be focused on. (Jaspers, 1976, p.94)

He recommends we practise meditation daily, penetrating truthfully into all facets of our thinking, feeling, speaking and acting. (see Jaspers, 1976, p.94) When we aim to help the pupil towards self-realization in his life in a more mature phase of his life, we can draw him closer towards what Jaspers calls transcendent meditation.

As the guide of the train of philosophical thought I make myself sure of real Being, Transcendence. I decode the ciphers of Being with the help of poetry and art. I make them comprehensive towards philosophical presentification. I search to be sure of what is independent of time or eternal in time and try to touch the origin of my freedom and throughout it, Being itself, I try to go down to the ground as if it were a co-knowledge of the creation. (Jaspers, 1976, p.94)

These two meditations have to be completed by one on the question: "What is to be done at that moment?" (Jaspers, 1971, p.94) In the case that I am losing the Encompassing sense in the indispensable intensity of purposeful thinking, "remembering one's own life in community is the background, or what the present task can make clear even in the minor details of that day."xii (Jaspers, 1976, p.94/5) Reflections of that type must be introduced naturally in the daily life of the pupil in the most common situations up to the point at which he feels that signifying them guides him. To do that the educator has to share these questionings with his pupil and make them feel the importance of these without being tempted to moralize. That is only possible for a person that himself is on the way of a philosophical life and insists on the principle that his pupil needs to find his own existence, and the ciphers that gives sense to his life. He has to be an authority for the pupil in terms of truthfulness, coherence, in speaking and acting without the will to be initiated into his position and convictions. ${ }^{\text {xiii }}$ As in all ambitious pedagogical thinking, the education of the 
educators is the Achilles' heel. It may be partially helpful to propose training and lessons but the most necessary, indispensable and challenging part of the educator's education is selfeducation.

We notice that the demands of Jaspers' philosophy on educational acting are extremely exacting. It does not combine with today's mainstream thinking in which Bauman's social diagnostics detected the tendency to transform all the areas of our lives into something that is liquid, without fixed rules, valid norms, truth, confidence, and commitment. Everything points to the possibility that this prognosis is always being transformed more and more on purpose: the hallucination for endless innovations, technological and scientific progress and infinite possibilities so as only to create keeping the mass of people staring at what is in front of them. Their subjectivity is led and reduced principally to being a good consumer and producer. The existential experiences of former generations always lose more importance for the present so that it seems radically different from all that has been. At no time prior to today have we had such easy access to deep human experience, fixed in ciphers throughout recorded history. Nevertheless, at the same time, they are regarded as antiquated, worthless, liquid, and sometimes as an exotic pastime or mere objects of erudition. Currently we stand actually before a historical and existential decision. Objectivism by defining the progress of science and Subjectivism by absolutizing the arbitrary will seem to become a more and more perfect married couple. First, consequences appear in all aspects of our lives as expressions of deep dehumanization. The reflection on the subject-object relation indicates the necessity to abandon these extremes and long for a well-balanced and differentiated view of this. In Jaspers we find a proposal resulting from deep reflection which confronts us with the new, and at the same time, it gives value to the past without dogmatism or conservationism. It is up to us to whether or not to accept the enormous and exacting pedagogical task of leaving the mainstream so as to embark as educators on a philosophical life that can have an indirect and with it the most efficient effect possible on our pupil.

\section{REFERENCES}

ARENDT, Hannah. Karl Jaspers: bürger der welt. In: Karl Jaspers. Ed. by Paul Arthur Schilpp. Stuttgart: Kohlhammer, 1957, p. 532-543.

BARTH, Karl. Phänomene des menschlichen. In: Dogmatik, III/2. Zollicon-Zürich: Evangelischer Verlag, 1948, p. 128-143.

EHRLICH, Leonard. Karl Jaspers: philosophy as faith. Amherst: University of Massachusetts Press, 1975.

HERSCH, Jeanne. Karl Jaspers - eine einführung in sein werk. München: R. Piper \& Co. Verlag, 1980.

JASPERS, Karl. Der philosophische glaube angesichts der offenbarung. München: R. Piper, 1962.

JASPERS, Karl. Einführung in die philosophie. 17th Ed. München: Piper, 1976.

\begin{tabular}{l|l|l|l|l|l|l} 
(C) ETD-Educ. Temat. Digit. & Campinas, SP & v.18 & n.3 & p.596-613 & jul./set.2016 & ISSN 1676-2592
\end{tabular}


JASPERS, Karl. Von der wahrheit. München: R. Piper, 1947.

JASPERS, Karl. Wahrheit und bewährung: philosophieren für die praxis. München: R. Piper, 1983.

KORO-LJUNGBERG, Mirka; CARLSON, David; TESAR, Marek; ANDERSON, Kate. Methodology brut: philosophy, estatic thinking and some other (unfinished) things. Qualitative Inquiry, v. 21, n. 07, p. 612-619. Available in: 〈http://goo.gl/zwJIz9>. Access: 20 June 2016. ISSN 1552-7565.

PIPER, Klaus; SANER Hans (Eds.) Erinnerungen an Karl Jaspers. München, Zürich: R. Piper \& Co. Verlag, 1974.

RICOEUR, Paul. Philosophie und religion bei Karl Jaspers. In: Karl Jaspers. Ed. by P. A. Schilpp, Stuttgart: Kohlhammer, 1957, p. 604-636.

ST. PIERRE, Elisabeth Adams. The empirical and the new empiricisms. Cultural Studies $\leftrightarrow$ Critical Methodologies, v. 16, n. 02, p. 111-124. 2016. Available in: < http://goo.gl/UAagf1>. Access in: 20 June 2016. ISSN 1552-356X.

ST. PIERRE, Elisabeth Adams; JACKSON Alecia Y.; MAZZEI, Lisa A. New empiricisms and new materialisms: conditions for new inquirity. Cultural Studies $\leftrightarrow$ Critical Methodologies, v. 02, n. 16, p. 99-110. 2016. Available in: 〈http://goo.gl/asvuVA 〉. Access in: 20 June 2016. ISSN 1552-356X.

TILLIETTE, Xavier. Sinn, wert und grenze der ciffrenlehre. Reflektionen über die metaphysik von Karl Jaspers. Studia Philosophica XX, 115-131. 1960.

WERNER, Martin. Existenzphilosophie und christentum. In: Schweizerische Theologische Rundschau, v. 23, n. 1/2, p. 21-40. 1953.

\footnotetext{
${ }^{i}$ We do not use the word pupil in it restrict sense of a learner in formaly estructurated educational space, but more widely for anyone who is to be educated in any situation. In less traditional dictionarys we find the word educand for it.

ii The editors have asked us to indicate how Jaspers' thinking relates to the recent turn to new empiricism/new materialism. A systematic comparison is only possible in another text with that specific purpose. To prevent interruptions in the flow of our presentation we resolved to attend to their request in some footnotes at the very points where polemical aspects appear. That is the case of the division of subject and object or subject-objectsplit, which is what Jaspers frequently calls it. In the new empiricism/new materialism we can identify attempts to overcome this. St. Pierre (2016) characterizes the plane of immanence as follows: It "does not begin with the necessity of human consciousness, human thought, or of any necessity. Again, it is pre-individual, preconsciousness, preconception, formless, depthless - but not inert. It is an extensive continuum of movement, forces, speeds, and intensitivities of the virtual that have not yet become actual." (p. 119) For Jaspers, such affirmations, true or not, cannot be found and uttered without subjectivity playing a part. It may be that in fact reality is that, but it is impossible to know this. For Jaspers the human condition is that we do not and cannot have a perception of reality as it itself is.

iii Koro-Ljungberg et al. (2015) identified a similar methodological problematic in recent philosophy: "It is from this heritage that philosophy as method has emerged and been elevated, encapsulating the thinking of the unthinkable through Foucault, Derrida, Deleuze and Guattari, Barad, and others." (p. 617) That does not mean that their thinking aims in the same direction.
} 
iv In relation to the comprehension of the philosophical faith see the extensive research of Leonard Ehrlich (1975) "Karl Jaspers: Philosophy as Faith."

' It is a characteristic of Jaspers' Periechontology that he tries to integrate classical philosophical thinking by searching for its right place and its limits of validity. That is different from philosophies, which constitute themselves by determining their foundational assumptions mostly in opposition to another philosophy. In this case the new philosophy makes itself largely dependent on its opposite. It is not difficult to find critiques of any philosophy. Nevertheless, if one is fixed on criticizing a certain philosophy, it can easily occur that sight is lost of other aspects of reality.

vi That step from immanence to transcendence is one of the most polemical in modern philosophy. The New empiricism/new materialism tries to restrict their new ontology to mere immanence. The question is whether that is possible. Immanence and transcendence are complementary notions. Can one exist without the other? Is immanence, that "has no outside" (St. Pierre, 2016, p. 120), possible? It may be that these questions are dismissed as Cartesian form of thinking that can be disregarded. In that case we can formulate other questions. Postulating reality as mere immanence includes the affirmation that there is nothing byond immanence. Can that be confirmed empirically? Could it be that affirmation itself is a transcending act?

vii The possibility of having the experience of being ourselves is one of the most important assumptions of Jaspers' philosophy. There is extensive discussion in modern philosophy about the question of whether an I does or does not exist. In general we find arguments contra the existence of a transcendental I. But in Jaspers the question is about an existential I. That cannot be confirmed or denied in a general way. Therefore Jaspers cannot follow Nietzsche in his affirmation that "I" is a fiction (St. Pierre et al. 2016, p. 103). If it was a fiction for Nietzsche, this is not necessarily so for everyone. The existential I can only be experienced in privileged instants by the individual who tries to unveil it. A different position is expressed in what Koro-Ljungberg et al. (2015) called ecstatic thinking. "It is an 'attitude' that involves a constant provocation with oneself and of others in an attempt to escape oneself." (p. 616) In Jaspers' view what we have to escape from are only the external influences that blur our I, and that is one of the fundamental conditions if we are to discover what we inmost are. We can hardly find what we deny in its existence, especially when it is very irksome to perceive it.

viii Therefore, the humanism in Jaspers is not a universal humanism in terms of an equal aggregate of human values supposedly present in everyone, which is widely criticised in post-human philosophy. Each person is responsible for finding out which values are unconditional for him. At the same time, the process to find them, entails showing proportionate tolerance with respect to others who are also on the way to finding their Existence. We can call it an existential humanism that deeply respects human differences.

ix At that point, we can ask if the vitalist view of matter defended by the new-empiricism/new-materialism can be identified as a cipher of Transcendence in Jaspers' comprehension, in view of the fact that that position is considered by its adherent as a new basis for acting ethically in the world. We cannot affirm that at the same time we believe in Nietzsche's assumption that there is no doer who precedes the deed (St. Pierre et all. 2016, p. 103 and 105). The question for Jaspers is if individuals as Existence recognize that cipher as an unconditional orientation for its realisation. Therefore, it cannot be the new philosophy by itself which provokes new ethical acting. Nor can the matter that is considered vital assume co-responsibility for an ethical change. For Jaspers it is only the single person as a possible Existence in communication with other Existences who can bring about real ethical change on the way. The new philosophy can demonstrate ethical aberrations in history, can alert to the need for a deeper comprehension of the dramatic situation of the world (as Jaspers did very early with regard to the danger of the atomic bomb. Hannah Arendt (1957) synthesized the political imperative present in Jaspers' philosophical reflections on that danger: in politics "nothing should be done which is contrary to the actual existing solidarity of mankind." (p. 543), but nothing of that brings a real change if it does not touch human beings in an existential form. In Jasper's view humans have to share the responsibility among themselves vis-àvis the reality that is given, and seek an urgent response, and examine what the possibilities are as to what the realm of ciphers offers as possible orientation. That means that he certainly would not accept a co-responsibility of matter, based on a vitalist view, nor consider that view as the only possible truth. What is possible is that the vitalist view of matter becomes a cipher for the Existence that finds itself to be authentic by following it.

\footnotetext{
x As to Jaspers' relation to religion and its rejection see Barth (1948), Werner (1952), Ricoeur (1957) and Tilliette (1960)

${ }^{x i}$ We can find a lot of similar affirmations in the new philosophy. The main difference from Jaspers' thinking is that for him Vernunft is only possible if based on Existence.
} 
xii To exercise these two types of meditation and read and reread the great philosophers is Jaspers' method of philosophy and doing these things is what made it possible for him to develop his Periechontology.

xiii In the collection "Memories of Karl Jaspers" (Piper \& Saner, ed. 1974) we can find confirmations of Jaspers' coherence to that attitude as an educator in every account of his former students.

FERDINAND ROHR

Doutor em Pedagogia pela RWTHA Aachen University, Aachen - Alemanha. Professor Titular da Universidade Federal do Pernambuco, UFPE, Recife, PE - Brasil.

E-mail: frohr@uol.com.br.

Recebido em: $15 / 12 / 2015$

Aprovado para publicação em: 30/06/2016

Como citar este documento:

RÖHR, Ferdinand. The Subject-Object-Relationship in Karl Jaspers' Periechontology - A Contribution to an Education for Openness, Tolerance and Existential Realization. ETD - Educação Temática Digital, Campinas, SP, v. 18, n. 3, p. 596-613, ago. 2016. ISSN 1676-2592. Disponível em:

<http://periodicos.sbu.unicamp.br/ojs/index.php/etd/article/view/8646186>. Acesso em: 30 ago. 2016. doi:http://dx.doi.org/10.20396/etd.v18i3.8646186. 